\title{
Effects of Re Content and Fabrication Process on Microstructural Changes and Hardening in Neutron Irradiated Tungsten
}

\author{
Makoto Fukuda*1, Takashi Tanno*2, Shuhei Nogami and Akira Hasegawa \\ Department of Quantum Science and Energy Engineering, Tohoku University, Sendai 980-8579, Japan
}

\begin{abstract}
The effects of the material fabrication process and rhenium $(\mathrm{Re})$ content on the irradiation-induced changes in the microstructure and hardness of pure tungsten (W) and W-Re alloys were investigated. Neutron irradiation of pure W and W-Re alloys (Re concentration 3-26\%) was carried out in the experimental fast reactor JOYO. The irradiation conditions were 0.44 displacement per atom (dpa) at $531^{\circ} \mathrm{C}$ and $0.47 \mathrm{dpa}$ at $583^{\circ} \mathrm{C}$ for pure $\mathrm{W}$ and $\mathrm{W}-\mathrm{Re}$ alloys, respectively. After irradiation, microstructural observations using a transmission electron microscope (TEM) and Vickers microhardness tests were performed.

Voids and dislocation loops were observed in both pure $\mathrm{W}$ and $\mathrm{W}-\mathrm{Re}$ alloys after irradiation. The number density of voids in pure $\mathrm{W}$ was higher than that in W-3\%Re, W-5\%Re and W-10\%Re. Only in the case of W-26\%Re irradiated to 0.47 dpa at $583^{\circ} \mathrm{C}$ were there no voids observed, but irradiation-induced fine precipitates and a few dislocation loops were observed. The irradiation hardening of pure W was greater than that of the W-Re alloys. It was considered that irradiation hardening of pure W was caused mainly by the higher number density of voids. The addition of Re suppressed void formation and irradiation hardening of the W-Re alloys. Irradiation hardening of W was also suppressed in hot-rolled W compared with arc-melted as-cast W. [doi:10.2320/matertrans.MBW201110]
\end{abstract}

(Received December 1, 2011; Accepted September 12, 2012; Published October 24, 2012)

Keywords: tungsten, tungsten-rhenium alloy, neutron irradiation, microstructural development, irradiation hardening

\section{Introduction}

Tungsten (W) is a candidate for armor material in divertors and first walls in fusion reactors because of its high melting point, thermal conductivity, and sputtering resistance. During the operation of a fusion reactor, armor materials are exposed to high-energy $(14 \mathrm{MeV})$ neutron irradiation and a high heat flux of approximately $10 \mathrm{MW} / \mathrm{m}^{2}{ }^{1)}$ As a result of neutron irradiation, the microstructure and material properties change because of displacement damage and nuclear transmutation. Several researchers have studied the effects of irradiation on W. For example, void swelling, ${ }^{2,3)}$ irradiation hardening, ${ }^{4-6)}$ and an increase in the ductile-brittle transition temperature (DBTT) after fission-neutron irradiation have been reported. ${ }^{7)}$ Nuclear transmutation resulting from high-fluence neutron irradiation is also predicted to occur in a fusion reactor. ${ }^{8)}$ Rhenium ( $\mathrm{Re}$ ) is one of the major solid transmutation elements of W. Bolt et al. predicted that the Re concentration and displacement damage of pure $\mathrm{W}$ in a DEMO reactor would be $6 \%$ and 30 displacement per atom (dpa), respectively, at the first wall and $3 \%$ and $15 \mathrm{dpa}$, respectively, at the divertor during five year operation period. ${ }^{1)}$

The degradation of the structural component materials resulting from neutron irradiation needs to be ascertained to ensure the safety and reliability of a fusion reactor. Irradiation embrittlement caused by hardening is considered a major cause for concern in irradiated $\mathrm{W}$ during the practical operation period. We have studied the irradiation behavior of $\mathrm{W}$ and various $\mathrm{W}$ alloys in different types of fission reactors. $^{9-13)} \mathrm{W}-26 \% \mathrm{Re}$, which is a solid-solution singlephase alloy prior to irradiation, has been widely used as an industrial material for high-temperature applications. However, fine and dense precipitates such as WRe (sigma phase) and $\mathrm{Re}_{3} \mathrm{~W}$ (chi phase) can be observed in the alloy

\footnotetext{
${ }^{* 1}$ Graduate Student, Tohoku University

${ }^{*}$ Present address: Japan Atomic Energy Agency
}

after irradiation of several dpa. ${ }^{5)}$ Although the solute Re improves the mechanical properties of $\mathrm{W},{ }^{14-16)}$ the irradiation-induced precipitates cause severe irradiation hardening and embrittlement. ${ }^{9,10,13)}$

The mechanical properties of $\mathrm{W}$ also change depending on the fabrication process, including the subsequent heat treatment. Different fabrication processes and heat treatments change the grain structure, such as grain size and shape, as well as other aspects of the microstructure, such as dislocation and defect density. The synergistic effects of irradiation damage and nuclear transmutation in $\mathrm{W}$ have not been investigated for $\mathrm{W}$ fabricated by different processes. Thus, the objective of this study is to investigate the effect of the material fabrication process and Re content on the microstructural and hardness changes of $\mathrm{W}$ and $\mathrm{W}-\mathrm{Re}$ alloys under neutron irradiation.

\section{Experimental Procedure}

Pure $\mathrm{W}$ and $\mathrm{W}-\mathrm{Re}$ ( Re concentration 3-26\%) alloys were examined in this study. Table 1 shows the chemical compositions of the alloys with interstitial-type impurities.

Table 1 Interstitial impurity levels of specimens.

\begin{tabular}{|c|c|c|c|c|c|c|}
\hline Type & Alloy & W & $\begin{array}{c}\mathrm{Re} \\
(\operatorname{mass} \%)\end{array}$ & $\begin{array}{c}\mathrm{C} \\
\text { (mass ppm) }\end{array}$ & $\begin{array}{c}\mathrm{O} \\
\text { (mass ppm) }\end{array}$ & $\begin{array}{c}\mathrm{N} \\
\text { (mass ppm) }\end{array}$ \\
\hline \multirow{5}{*}{$\begin{array}{c}\text { Hot-rolled } \\
\text { sheet } \\
(\mathrm{HR})\end{array}$} & Pure W & bal. & - & $<30$ & $<30$ & $<10$ \\
\hline & $\mathrm{W}-3 \% \mathrm{Re}$ & bal. & 3.0 & 3 & 16 & $<10$ \\
\hline & $\mathrm{W}-5 \% \mathrm{Re}$ & bal. & 5.0 & 20 & 37 & $<10$ \\
\hline & $\begin{array}{l}\text { W-10\% } \\
\operatorname{Re}\end{array}$ & bal. & 9.1 & 15 & 52 & $<10$ \\
\hline & $\begin{array}{l}\text { W-26\% } \\
\operatorname{Re}\end{array}$ & bal. & 26.0 & $<30$ & $<30$ & $<10$ \\
\hline \multirow{2}{*}{$\begin{array}{l}\text { Arc-melted } \\
\text { ingot (AC) }\end{array}$} & Pure W & bal. & - & 17 & 39 & $<6$ \\
\hline & $\begin{array}{l}\mathrm{W}-26 \% \\
\operatorname{Re}\end{array}$ & bal. & 26.2 & 9 & 17 & $<6$ \\
\hline
\end{tabular}


W-Re alloys were used to simulate the effects of changes in the composition of materials resulting from nuclear transmutation under neutron irradiation. All the specimens were disk-shaped ( $3 \mathrm{~mm}$ in diameter and $0.2 \mathrm{~mm}$ thick). In this study, two types of materials were used. The first type of material was a hot-rolled sheet $0.2 \mathrm{~mm}$ thick supplied by Plansee Ltd. Disk-shaped specimens were punched out from the sheet and heat treated at $1400^{\circ} \mathrm{C}$ for $1 \mathrm{~h}$ in vacuum. These specimens are denoted as pure W (HR) and W-Re (HR) in this paper. The second type of material was fabricated by arc-melting process at the Institute for Materials Research, Tohoku University. The raw materials were pure $\mathrm{W}$ and W-26\%Re rods supplied by Plansee Ltd. The interstitial impurity levels of the fabricated alloys were in the range 40-200 wppm for carbon (C), 20-40 wppm for oxygen (O), and less than $12 \mathrm{wppm}$ for nitrogen $(\mathrm{N})$. Disk-shaped specimens were cut out from the ingots by electricaldischarge machining. The specimens were heat treated at $1400^{\circ} \mathrm{C}$ for $1 \mathrm{~h}$ in vacuum to anneal the machine-worked surface layer. The structure of the heat-treated specimens was considered to be an as-solidified structure owing to the arc melting. These specimens had an as-cast structure; therefore, they are described as pure $\mathrm{W}(\mathrm{AC})$ and $\mathrm{W}-\mathrm{Re}(\mathrm{AC})$ in this paper.

Figure 1 shows the results of the Vickers microhardness test of the as-hot-rolled sheet specimens and that of the as-

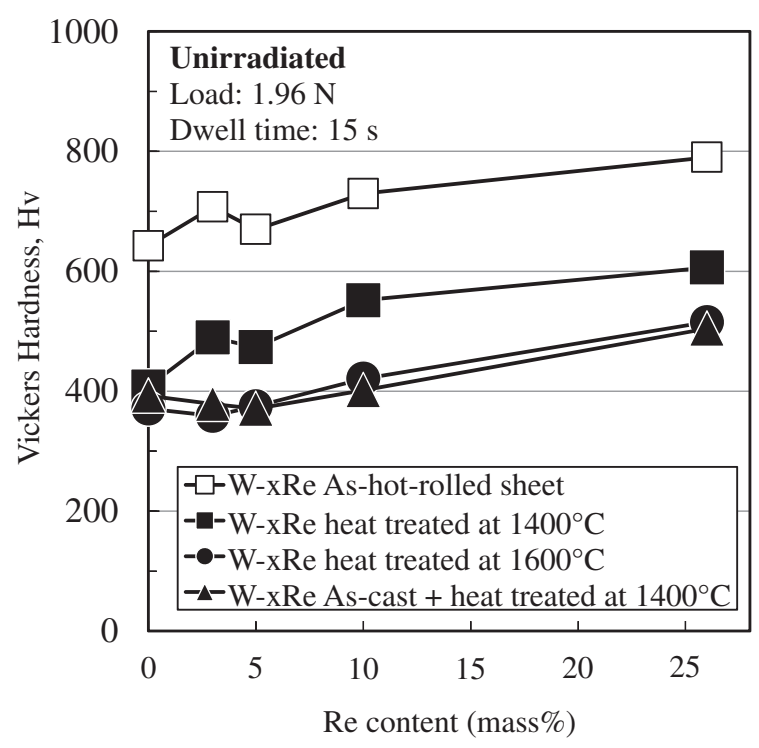

Fig. 1 Vickers microhardness of unirradiated specimens. cast specimens after heat treatment at $1400^{\circ} \mathrm{C}$, respectively. The Vickers microhardness of the sheet specimens without heat treatment and after being heat treated at $1600^{\circ} \mathrm{C}$ (HT: 1600) for $1 \mathrm{~h}$ are shown in the figure as a reference. The hardness of the sheet specimens decreased after heat treatment at $1400^{\circ} \mathrm{C}$.

The average grain size was $13.5,60 \times 23,70 \times 15$ and $14 \mu \mathrm{m}$ for pure W (HR), W-10\%Re (HR), W-26\%Re (HR) and pure W (HT: 1600), respectively. The grain morphology of $\mathrm{W}-10 \% \mathrm{Re}(\mathrm{HR})$ and $\mathrm{W}-26 \% \mathrm{Re}(\mathrm{HR})$ consisted of elongated grains and the grain size is given in terms of length $\times$ width. In the case of the AC specimens, the average grain size was greater than $100 \mu \mathrm{m}$ and the effect of the addition of $\mathrm{Re}$ on the grain size was relatively small. The hardness of pure W (HR) and pure W (HT: 1600) were almost the same, indicating that hot-rolled pure $\mathrm{W}$ can be recrystallized at temperatures above $1400^{\circ} \mathrm{C}$. The hardness of the hot-rolled $\mathrm{W}-\mathrm{Re}$ alloys heat treated at $1400^{\circ} \mathrm{C}$ was larger than that of those heat treated at $1600^{\circ} \mathrm{C}$.

Figure 2 shows the results of microstructural observations of pure $\mathrm{W}, \mathrm{W}-5 \% \mathrm{Re}(\mathrm{HR}), \mathrm{W}-10 \% \mathrm{Re}(\mathrm{HR})$ and $\mathrm{W}-26 \% \mathrm{Re}$ (HR) prior to irradiation. As shown in the figure, a subgrain structure remained in all specimens that contained Re. It has been reported that the recrystallization temperature of $\mathrm{W}$ is increased by the addition of Re. ${ }^{17)}$ These results show that the W-Re (HR) alloys with Re contents of 3-26\% were in a stress-relieved state and that the W-Re (HT: 1600) alloys were in a fully recrystallized state.

A neutron-irradiation experiment was conducted in JOYO, which is a fast experimental reactor operated by Japan Atomic Energy Agency (JAEA). Specimens ( $3 \mathrm{~mm}$ in diameter, $0.2 \mathrm{~mm}$ thick) were irradiated in helium-filled capsules. The neutron irradiation conditions are listed in Table 2. The displacement damages (dpa) and irradiation temperatures were $0.44 \mathrm{dpa}$ at $531^{\circ} \mathrm{C}$ and $0.47 \mathrm{dpa}$ at $583^{\circ} \mathrm{C}$ for pure $\mathrm{W}$ and $\mathrm{W}-\mathrm{Re}$ alloys, respectively. The dpa was calculated according to the NPRIM-1.3 code $^{18)}$ using $90 \mathrm{eV}$ as the displacement threshold energy of $\mathrm{W} .{ }^{19)}$

Table 2 Neutron irradiation conditions.

\begin{tabular}{ccc}
\hline $\begin{array}{c}\text { Irradiation } \\
\text { temperature } \\
\left(T /{ }^{\circ} \mathrm{C}\right)\end{array}$ & $\begin{array}{c}\text { Neutron fluence } \\
\left(10^{25} \mathrm{n} \cdot \mathrm{m}^{-2}\right) \\
\left(E_{\mathrm{n}}>0.1 \mathrm{MeV}\right)\end{array}$ & $\mathrm{dpa}^{*}$ \\
\hline 531 & 3.4 & 0.44 \\
583 & 3.7 & 0.47 \\
\hline
\end{tabular}

$* 1 \mathrm{dpa}=8 \times 10^{25} \mathrm{n} / \mathrm{m}^{2}\left(E_{\mathrm{n}}>0.1 \mathrm{MeV}\right), E_{\mathrm{d}}=90 \mathrm{eV}$.

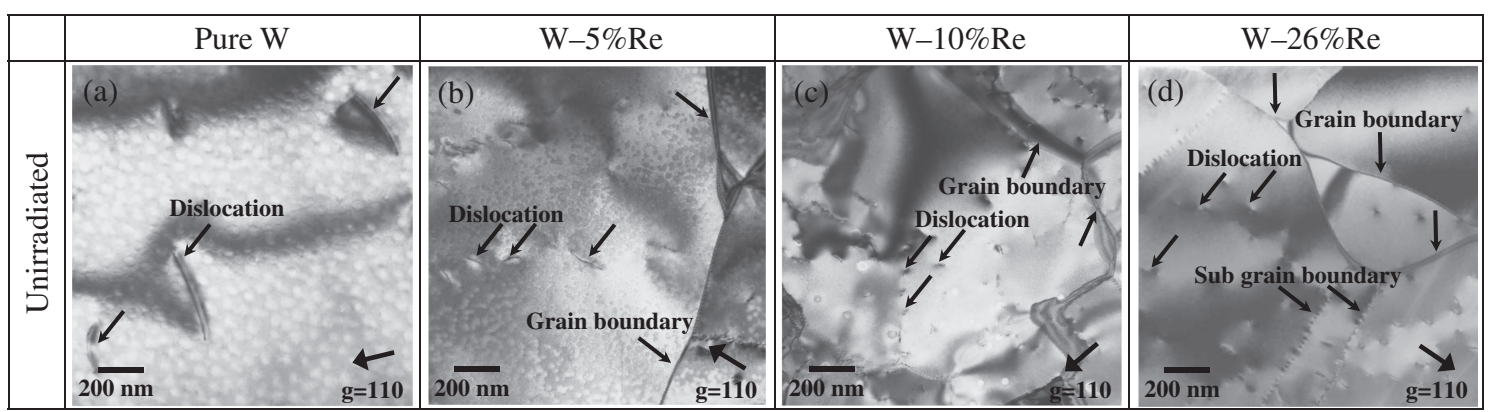

Fig. 2 Microstructures of pure W (HR), W-5\%Re (HR), W-10\%Re (HR) and W-26\% Re (HR) before irradiation. 


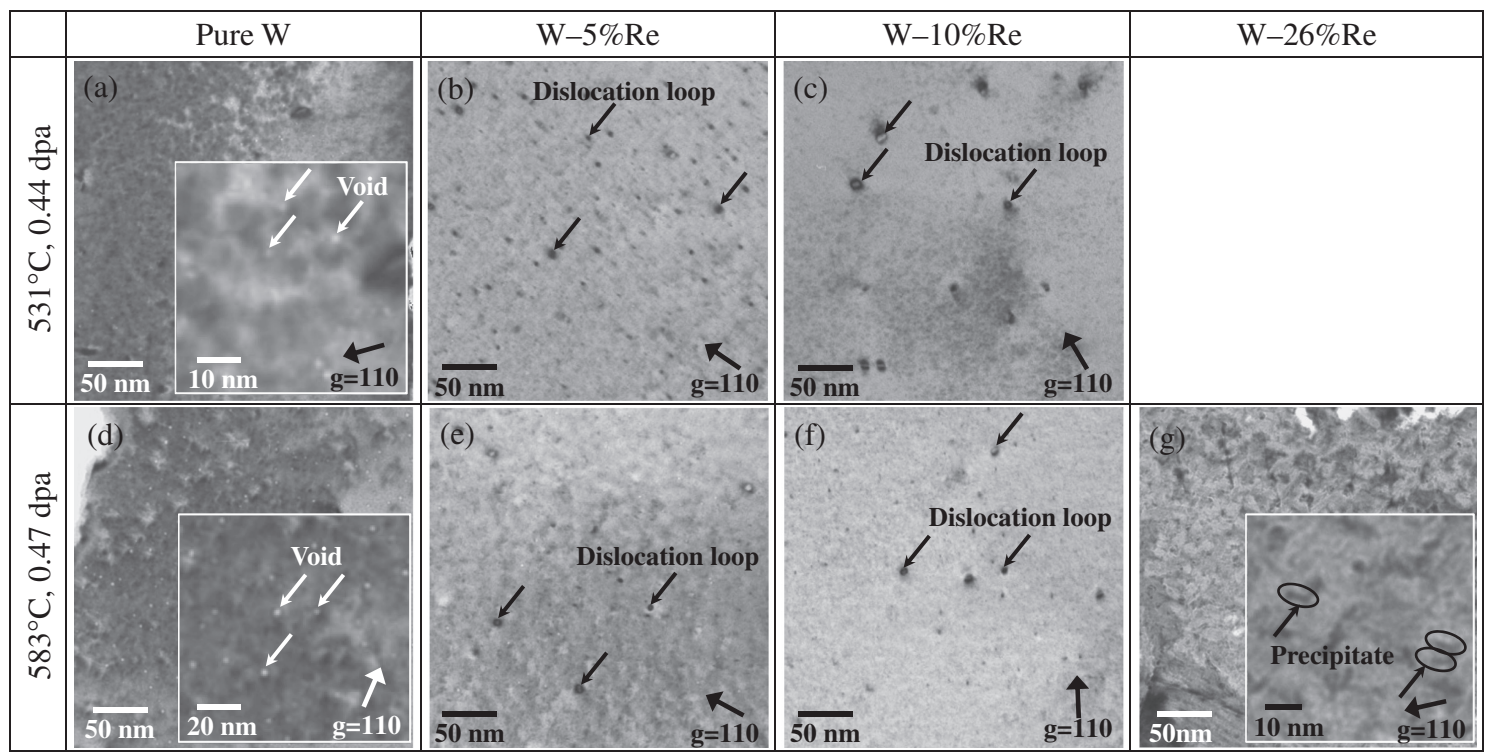

Fig. 3 Microstructures of pure W (HR), W-5\%Re (HR), W-10\%Re (HR) and W-26\% Re (HR) irradiated to $0.44 \mathrm{dpa}$ at $531^{\circ} \mathrm{C}$ or $0.47 \mathrm{dpa}$ at $583^{\circ} \mathrm{C}$.

Table 3 Size and number density of irradiation-induced defect clusters in HR specimens.

\begin{tabular}{|c|c|c|c|c|c|c|c|}
\hline \multirow[b]{2}{*}{$\begin{array}{l}\text { Irradiation } \\
\text { conditions }\end{array}$} & \multirow[b]{2}{*}{ Specimen } & \multicolumn{2}{|c|}{ Void } & \multicolumn{2}{|c|}{ Dislocation loop } & \multicolumn{2}{|c|}{ Precipitate } \\
\hline & & $\begin{array}{c}\text { Diameter, } \\
d / \mathrm{nm}\end{array}$ & $\begin{array}{c}\text { Density, } \\
N / 10^{22} \mathrm{~m}^{-3}\end{array}$ & $\begin{array}{c}\text { Diameter, } \\
d / \mathrm{nm}\end{array}$ & $\begin{array}{c}\text { Density, } \\
N / 10^{22} \mathrm{~m}^{-3}\end{array}$ & $\begin{array}{c}\text { Diameter, } \\
d / \mathrm{nm}\end{array}$ & $\begin{array}{c}\text { Density, } \\
N / 10^{22} \mathrm{~m}^{-3}\end{array}$ \\
\hline \multirow{4}{*}{$\begin{array}{c}531^{\circ} \mathrm{C} \\
0.44 \mathrm{dpa}\end{array}$} & Pure W & 1.1 & 19.0 & 7.5 & 1.3 & - & - \\
\hline & $\mathrm{W}-3 \% \mathrm{Re}$ & 1.4 & 0.03 & 3.7 & 4.6 & - & - \\
\hline & $\mathrm{W}-5 \% \mathrm{Re}$ & 1.7 & 0.2 & 2.9 & 1.4 & - & - \\
\hline & $\mathrm{W}-10 \% \mathrm{Re}$ & 3.4 & 0.1 & 7.1 & 0.3 & - & - \\
\hline \multirow{5}{*}{$\begin{array}{c}583^{\circ} \mathrm{C} \\
0.47 \mathrm{dpa}\end{array}$} & Pure W & 3.1 & 12.8 & $\sim 3$ & $<0.2$ & - & - \\
\hline & $\mathrm{W}-3 \% \mathrm{Re}$ & 1.9 & 0.2 & 2.1 & 1.2 & - & - \\
\hline & $\mathrm{W}-5 \% \mathrm{Re}$ & 1.6 & 0.3 & 2.2 & 1.3 & - & - \\
\hline & $\mathrm{W}-10 \% \mathrm{Re}$ & 3.9 & 0.05 & 4.5 & 0.6 & - & - \\
\hline & $\mathrm{W}-26 \% \operatorname{Re}$ & - & - & - & - & 2.8 & 3.9 \\
\hline
\end{tabular}

After irradiation, microstructural observations of pure W (HR) and W-Re (HR) alloys were conducted using a transmission electron microscope (TEM) at the International Research Center for Nuclear Materials Science of the Institute for Materials Research, Tohoku University. The thicknesses of the observed foil specimens were estimated using the thickness-fringe method under $g=110$ diffraction conditions in order to measure the number density of irradiation damage clusters such as voids, dislocation loops, and precipitates. Voids were identified using black/white contrast changes. The dislocation loops, black dots, and precipitates were identified by a weak-beam method for $g=110$. By this method, voids and dislocation loops were successfully distinguished. Vickers microhardness tests before and after irradiation were conducted at room temperature, and the indentation load and dwell time were $1.96 \mathrm{~N}$ and $15 \mathrm{~s}$, respectively.

\section{Results and Discussion}

Figure 3 shows the results of the microstructural observation of pure W (HR), W-5\%Re (HR), W-10\%Re (HR) and
$\mathrm{W}-26 \% \mathrm{Re}(\mathrm{HR})$ after irradiation. In the case of pure $\mathrm{W}(\mathrm{HR})$ irradiated to $0.44 \mathrm{dpa}$ at $531^{\circ} \mathrm{C}$ and to $0.47 \mathrm{dpa}$ at $583^{\circ} \mathrm{C}$, voids and dislocation loops were observed. As for the specimens containing Re, a few black dots and dislocation loops were observed and the number density of the voids was significantly lower compared with that of pure W (HR). In $\mathrm{W}-26 \% \mathrm{Re}(\mathrm{HR})$ irradiated to $0.47 \mathrm{dpa}$ at $583^{\circ} \mathrm{C}$, fine needle-like precipitates and a few dislocation loops were observed. Because the amount of precipitate was minimal, the precipitate could not be identified by using a diffraction pattern. However, the shape and direction of the precipitates were the same as those observed in our previous studies, ${ }^{9,11,13)}$ and it is therefore considered that the precipitates in $\mathrm{W}-26 \% \mathrm{Re}(\mathrm{HR})$ are chi-phase precipitates. Precipitates were not observed when the Re content was below 10 mass $\%$.

Table 3 shows the mean size and number density of voids, dislocation loops, black dots and precipitates observed in pure W (HR) and the W-Re (HR) alloys. In the table, the mean size and number density of the dislocation loops include those for black dots. The mean size and number density of voids in pure $\mathrm{W}(\mathrm{HR})$ irradiated at $531^{\circ} \mathrm{C}$ were 


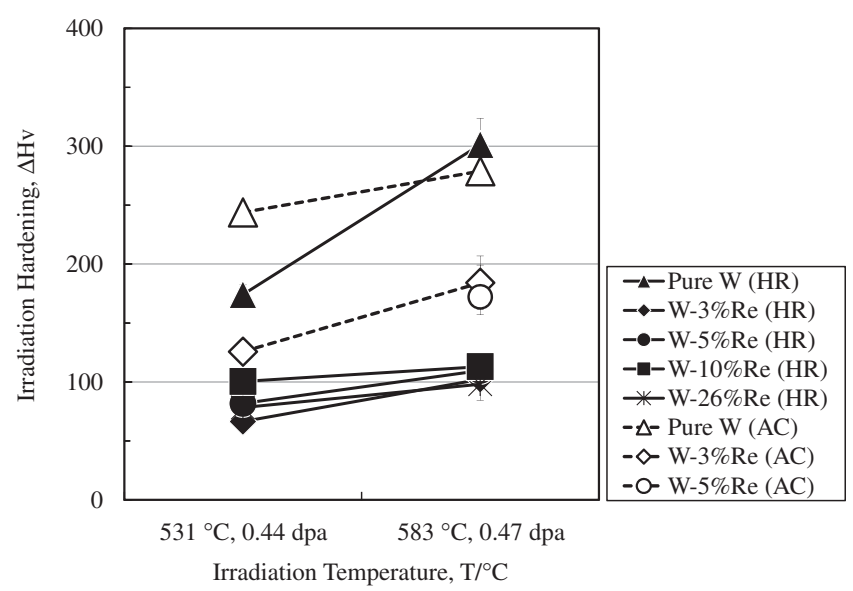

Fig. 4 Irradiation hardening of pure $\mathrm{W}$ and $\mathrm{W}-\mathrm{Re}$ alloys.

$1.1 \mathrm{~nm}$ and $19.0 \times 10^{22} / \mathrm{m}^{3}$, respectively; for $583^{\circ} \mathrm{C}$ irradiation, the mean size and number density of voids were $3.1 \mathrm{~nm}$ and $12.8 \times 10^{22} / \mathrm{m}^{3}$, respectively. Thus, for pure $\mathrm{W}$ (HR) irradiated at $531^{\circ} \mathrm{C}$, the mean size was smaller and the number density was larger than that for irradiation at $583^{\circ} \mathrm{C}$. It was considered that nucleation of voids mainly occurred in pure $\mathrm{W}(\mathrm{HR})$ irradiated at $531^{\circ} \mathrm{C}$. Nucleation and growth of voids occurred in pure $\mathrm{W}(\mathrm{HR})$ irradiated at $583^{\circ} \mathrm{C}$. However, void formation was suppressed in the $\mathrm{W}-3 \% \mathrm{Re}(\mathrm{HR}), \mathrm{W}-$ $5 \% \operatorname{Re}(\mathrm{HR})$ and $\mathrm{W}-10 \% \operatorname{Re}(\mathrm{HR})$ specimens. The number density of voids in these Re-containing specimens was less than $1 / 100$ that of pure W (HR). Only a few fine precipitates were observed in $\mathrm{W}-26 \% \mathrm{Re}(\mathrm{HR})$ irradiated at $583^{\circ} \mathrm{C}$. The mean diameter and number density of the precipitates were $2.8 \mathrm{~nm}$ and $3.9 \times 10^{22} / \mathrm{m}^{3}$, respectively. The effect of irradiation temperature on the microstructural changes in the W-Re (HR) alloys (3-26\% Re) was smaller than that for pure W (HR).

Figure 4 shows irradiation hardening of the specimens. Irradiation hardening $\left(\Delta H_{\mathrm{V}}\right)$ was defined as an increase in the measured Vickers microhardness resulting from irradiation. The irradiation hardening of pure $\mathrm{W}$ was larger than that of the $\mathrm{W}-\mathrm{Re}$ alloys. In the case of $\mathrm{W}-3 \% \mathrm{Re}(\mathrm{HR})$ and $\mathrm{W}-5 \% \mathrm{Re}$ (HR), the irradiation hardening was smaller than that of the $\mathrm{AC}$ specimens. The irradiation hardening of pure $\mathrm{W}$ and the $\mathrm{W}-\mathrm{Re}$ alloys irradiated at $583^{\circ} \mathrm{C}$ tended to be larger than that of pure $\mathrm{W}$ and $\mathrm{W}-\mathrm{Re}$ alloys irradiated at $531^{\circ} \mathrm{C}$ for both the HR and the AC specimens. The temperature dependence of irradiation hardening for pure $\mathrm{W}$ was remarkable compared with that of the $\mathrm{W}-\mathrm{Re}$ alloys. The mean size of voids in pure $\mathrm{W}$ irradiated at $583^{\circ} \mathrm{C}$ was approximately three times larger than that in pure $\mathrm{W}$ irradiated at $531^{\circ} \mathrm{C}$ (Table 3 ). The temperature dependence of irradiation hardening in pure $\mathrm{W}$ might affect the difference in void formation behavior.

The measured and calculated values for the irradiation hardening of specimens heat treated at $1300^{\circ} \mathrm{C}$ are shown in Table 4. The calculations were based on eq. (1), shown below, as summarized by Moteff et al., ${ }^{20}$ where $\alpha$ is a constant depending on the irradiated alloy and defect cluster type, $\mu$ is the shear modulus, and $b$ is the Burgers vector.

$$
\Delta H=6 \alpha \mu b(N d)^{1 / 2}
$$

Table 4 Calculated and measured irradiation hardening of the HR specimens. $\Delta H_{\mathrm{V}}$ (calculated) and $\Delta H_{\mathrm{V}}$ (measured) are the irradiation hardening obtained by calculations based on the result of microstructure observations and by measurement, respectively.

\begin{tabular}{|c|c|c|c|c|c|c|c|}
\hline \multirow{2}{*}{$\begin{array}{l}\text { Irradiation } \\
\text { conditions }\end{array}$} & \multirow[b]{2}{*}{ Specimen } & \multicolumn{2}{|c|}{ Void } & \multicolumn{2}{|c|}{ Dislocation loop } & \multicolumn{2}{|c|}{$\Delta H_{\mathrm{V}}($ total $)$} \\
\hline & & $\begin{array}{c}(\mathrm{Nd})^{1 / 2} \\
\left(10^{6} \mathrm{~m}^{-1}\right)\end{array}$ & $\begin{array}{c}\Delta H_{\mathrm{V}} \\
\text { (Calc.) }\end{array}$ & $\begin{array}{c}(\mathrm{Nd})^{1 / 2} \\
\left(10^{6} \mathrm{~m}^{-1}\right)\end{array}$ & $\begin{array}{c}\Delta H_{\mathrm{V}} \\
\text { (Calc.) }\end{array}$ & Calc. & Meas. \\
\hline \multirow{4}{*}{$\begin{array}{c}531^{\circ} \mathrm{C} \\
0.44 \mathrm{dpa}\end{array}$} & Pure W & 14.4 & 204 & 9.7 & 48 & 210 & 174 \\
\hline & $\mathrm{W}-3 \% \mathrm{Re}$ & 0.7 & 9 & 13.0 & 64 & 65 & 66 \\
\hline & $\mathrm{W}-5 \% \mathrm{Re}$ & 1.9 & 26 & 6.5 & 32 & 42 & 82 \\
\hline & $\mathrm{W}-10 \% \mathrm{Re}$ & 1.8 & 26 & 4.6 & 23 & 35 & 100 \\
\hline \multirow{4}{*}{$\begin{array}{c}583^{\circ} \mathrm{C} \\
0.47 \mathrm{dpa}\end{array}$} & Pure W & 20.0 & 281 & 2.4 & 12 & 282 & 301 \\
\hline & $\mathrm{W}-3 \% \mathrm{Re}$ & 2.1 & 30 & 5.1 & 26 & 40 & 102 \\
\hline & $\mathrm{W}-5 \% \mathrm{Re}$ & 2.1 & 30 & 5.4 & 27 & 40 & 110 \\
\hline & $\mathrm{W}-10 \% \mathrm{Re}$ & 1.4 & 20 & 5.2 & 26 & 33 & 113 \\
\hline
\end{tabular}

The values of $\mu$ and $b$ of $\mathrm{W}$ are $151 \mathrm{GPa}$ and $0.2741 \mathrm{~nm}$, respectively. The units for $\Delta H$ are $\mathrm{GPa}$, and in the case of using Vickers microhardness, with units of $\mathrm{kgf} / \mathrm{mm}^{2}$, eq. (1) is converted to eq. (2):

$$
\Delta H_{\mathrm{v}}=\frac{6}{9.8} \alpha \mu b(N d)^{1 / 2}
$$

The value $\alpha_{1}=0.2$ for the dislocation loop was referred to in a previous report. ${ }^{21)}$ The value $\alpha_{\mathrm{v}}=0.6$ for the void was fixed by comparing the estimated values with the measured irradiation hardening. ${ }^{13)}$ The $\Delta H_{\mathrm{V}}$ (total) was calculated by the square root of the sum of the squares of each calculated $\Delta H_{\mathrm{V}}$ for voids and dislocation loops. These results show that the irradiation hardening of pure W (HR) was mainly caused by the voids, and the contribution of the dislocation loops was considered to be relatively small. In the case of pure W (HR) irradiated to $0.44 \mathrm{dpa}$ at $531^{\circ} \mathrm{C}$, the calculated value for irradiation hardening was larger than that of the measured value. The equation used in this work to calculate irradiation hardening was based on the Orowan mechanism, and it was confirmed that the calculated value shows good agreement with the measured value. ${ }^{20)}$ On the other hand, Singh et al. reported that irradiation often induced very small clusters or loops that could not prevent dislocation motion. ${ }^{22)}$ Thus, it is considered that there is a possibility that the calculation used in this study for irradiation hardening in pure $\mathrm{W}(\mathrm{HR})$ irradiated to $0.44 \mathrm{dpa}$ at $531{ }^{\circ} \mathrm{C}$ overestimated the effect of voids on the hardening. As for W-Re (HR) alloys with Re contents of $3-10 \%$, the calculated value of irradiation hardening was smaller than that of the measured value. It is considered that the irradiation hardening of these W-Re (HR) alloys is affected not only by the formation of voids and dislocation loops but also by other factors such as invisible radiation-induced $\mathrm{Re}$ precipitation. Re segregation in W-Re alloys caused by neutron irradiation was reported in a previous study. ${ }^{5)}$ In the case of $\mathrm{W}-26 \% \mathrm{Re}(\mathrm{HR})$, irradiation hardening was probably caused by the formation of irradiation-induced precipitates.

In our previous studies, neutron irradiations to $0.96 \mathrm{dpa}$ at $538^{\circ} \mathrm{C}$ and $0.37 \mathrm{dpa}$ at $500^{\circ} \mathrm{C}$ were carried out for pure $\mathrm{W}$ (AC) and W-Re (AC) alloys with Re contents of 5-26\%. ${ }^{10,13)}$ 


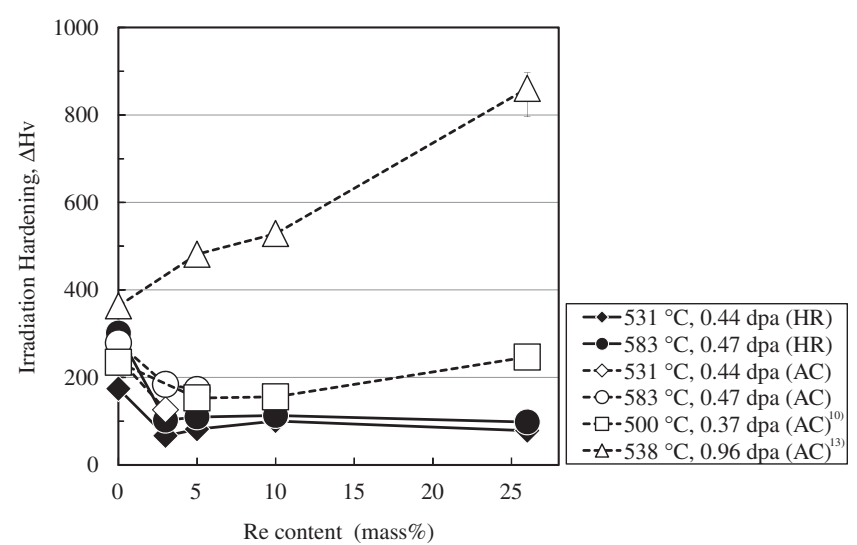

Fig. 5 Irradiation hardening of pure $\mathrm{W}$ and $\mathrm{W}-\mathrm{Re}$ alloys, including results from previous studies.

Figure 5 shows the irradiation hardening of pure $\mathrm{W}$ and W-Re alloys with Re contents of $3-26 \%$, including data from our previous studies. Irradiation hardening that occurred in pure $\mathrm{W}(\mathrm{AC})$ and $\mathrm{W}-\mathrm{Re}(\mathrm{AC})$ alloys $(5-26 \% \mathrm{Re})$ irradiated to $0.96 \mathrm{dpa}$ at $538^{\circ} \mathrm{C}$ was larger than that in pure $\mathrm{W}(\mathrm{HR})$ and $\mathrm{W}-\mathrm{Re}(\mathrm{HR})$ alloys (3-26\% Re). In the case of pure $\mathrm{W}(\mathrm{AC})$ irradiated to $0.96 \mathrm{dpa}$ at $538^{\circ} \mathrm{C}$, voids and dislocation loops were observed, and the sizes of the voids and dislocation loops were 2.1 and $4.7 \mathrm{~nm}$, respectively, and the number densities of the voids and dislocation loops were 48.7 and $4.7 \times 10^{22} / \mathrm{m}^{3}$, respectively. ${ }^{13)}$ The number densities were much larger than those in pure W (HR) irradiated to $0.44 \mathrm{dpa}$ at $531^{\circ} \mathrm{C}$, and this caused a large degree of irradiation hardening in pure W (AC) irradiated to $0.96 \mathrm{dpa}$ at $538^{\circ} \mathrm{C}$. Irradiation hardening of $\mathrm{W}-\mathrm{Re}$ alloys $(5-26 \% \mathrm{Re})$ irradiated to $0.96 \mathrm{dpa}$ at $538^{\circ} \mathrm{C}$ was mainly caused by precipitates. ${ }^{13)}$

From the comparison of the irradiation hardening of pure $\mathrm{W}$ irradiated to the same damage level, the effect of the fabrication process on irradiation hardening behavior of pure $\mathrm{W}$ was not clear. As mentioned above, the microstructures of both pure $\mathrm{W}(\mathrm{HR})$ and pure $\mathrm{W}(\mathrm{AC})$ were in a recrystallized state, and the effect of the fabrication process was not observed. In the case of the W-Re alloys, the effect of the fabrication process on irradiation hardening was observed. The microstructure of the W-Re (HR) alloys prior to irradiation was in a so-called stress-relieved state, and it contained defect sinks such as grain boundaries and dislocations. On the other hand, for the W-Re (AC) alloys that had been fully annealed, defect sink densities such as grain boundaries and dislocations are considered to be small. Therefore, defect cluster formation and hardening in $\mathrm{W}-\mathrm{Re}$ (HR) alloys (3-26\% Re) are more suppressed than in $\mathrm{W}-\mathrm{Re}$ (AC) alloys (3-26\% Re).

The effects of the addition of $\mathrm{Re}$ to pure $\mathrm{W}$ on the development of irradiation-defect structures were observed. Void formation and irradiation hardening were suppressed in the W-Re (HR) alloys. Williams et al. ${ }^{5)}$ suggested that solute $\mathrm{Re}$ and self-interstitial atoms tend to form an interstitialsolute complex such as a Re-W dumbbell. This Re-W dumbbell diffuses into the sinks and solute Re enrichment at the sinks occurs. This may be the process of the formation of a Re-segregated region and/or precipitates. The formation of a Re-W dumbbell may have another effect on damage structure evolution. When a Re-W dumbbell is formed, the mobility of self-interstitial atoms may decrease, which increases the probability of recombinations between vacancies and interstitial atoms and reduces the number of remaining vacancies. Consequently, the formation of vacancy clusters is suppressed. Therefore, the irradiation hardening of W-Re (HR) alloys (3-26\% Re) is due not only to voids, dislocation loops and black dots but also to invisible obstacles such as Re-segregated regions and precipitates.

\section{Summary}

The effects of the Re content and fabrication process of $\mathrm{W}$ and $\mathrm{W}-\mathrm{Re}$ alloys on the changes in the microstructure and hardness under neutron irradiation of $0.44 \mathrm{dpa}$ at $531^{\circ} \mathrm{C}$ and $0.47 \mathrm{dpa}$ at $583^{\circ} \mathrm{C}$ were investigated. The following results were obtained:

(1) In hot-rolled and heat-treated pure W (HR), voids and dislocation loops were observed but the irradiation hardening was mainly caused by voids. The amount of irradiation hardening of pure W (HR) was smaller than that of as-cast and arc-melted pure W (AC) irradiated at $531^{\circ} \mathrm{C}$, although the irradiation hardening was almost the same when irradiation was conducted at $583^{\circ} \mathrm{C}$. Although the difference in irradiation hardening behavior between pure W (HR) and pure $\mathrm{W}$ (AC) was not clear, it is considered that pure $\mathrm{W}$ (HR) was in a recrystallized state and the difference in sink density was relatively smaller than that in pure $\mathrm{W}(\mathrm{AC})$.

(2) In hot-rolled and heat-treated W-Re (HR) alloys, dislocation loops and voids were observed, although the number density of voids was significantly smaller than that in pure W (HR). Precipitates were observed only in $\mathrm{W}-26 \% \mathrm{Re}(\mathrm{HR})$ irradiated to $0.47 \mathrm{dpa}$ at $583^{\circ} \mathrm{C}$. The amount of irradiation hardening of the W-Re alloys was smaller than that of pure W. This was probably caused by a difference in the void-formation behavior of pure $\mathrm{W}$ and $\mathrm{W}-\mathrm{Re}$ alloys, and there is a possibility that the irradiation hardening of W-Re alloys is caused by not only voids and dislocation loops but also Resegregated region and precipitates.

(3) Irradiation hardening of hot-rolled and heat-treated $\mathrm{W}-\mathrm{Re}(\mathrm{HR})$ alloys was smaller than that of as-cast and arc-melted W-Re (AC) alloys. The small grain size and remaining cell structures and dislocations in the W-Re (HR) alloys were considered to be the reasons for the suppression of the formation of defect clusters and smaller hardening than that in as-cast specimens.

\section{Acknowledgements}

The post-irradiation experiments (PIE) were carried out at the International Research Center for Nuclear Materials Science of the Institute for Materials Research (IMR), Tohoku University. The authors thank Mr. Narui, Mr. Yamazaki, and the IMR staff for their assistance with the PIE. 


\section{REFERENCES}

1) H. Bolt, V. Barabash, W. Krauss, J. Linke, R. Neu, S. Suzuki, N. Yoshida and ASDEX Upgrade Team: J. Nucl. Mater. 329-333 (2004) 66-73.

2) R. C. Rau, R. L. Ladd and J. Moteff: J. Nucl. Mater. 33 (1969) 324 327.

3) J. Matolich, H. Nahm and J. Moteff: Scr. Metall. 8 (1974) 837-842.

4) R. C. Rau, J. Moteff and R. L. Ladd: J. Nucl. Mater. 24 (1967) 164 173.

5) R. K. Williams, F. W. Wiffen, J. Bentley and J. O. Stiegler: Metall. Trans. A 14 (1983) 655-666.

6) A. Hasegawa, T. Tanno, S. Nogami and M. Satou: J. Nucl. Mater. 417 (2011) 491-494.

7) J. M. Steichen: J. Nucl. Mater. 60 (1976) 13-19.

8) T. Noda, M. Fujita and M. Okada: J. Nucl. Mater. 258-263 (1998) 934 939.

9) Y. Nemoto, A. Hasegawa, M. Satou and K. Abe: J. Nucl. Mater. 283287 (2000) 1144-1147.

10) T. Tanno, A. Hasegawa, J. C. He, M. Fujiwara, S. Nogami, M. Satou, T. Shishido and K. Abe: Mater. Trans. 48 (2007) 2399-2402.
11) T. Tanno, A. Hasegawa, M. Fujiwara, J. C. He, S. Nogami, M. Satou, T. Shishido and K. Abe: Mater. Trans. 49 (2008) 2259-2264.

12) T. Tanno, A. Hasegawa, J. C. He, M. Fujiwara, S. Nogami, M. Satou, K. Abe and T. Shishido: J. Nucl. Mater. 386-388 (2009) 218-221.

13) T. Tanno, M. Fukuda, S. Nogami and A. Hasegawa: Mater. Trans. 52 (2011) 1447-1451

14) P. L. Raffo: J. Less-Common Metals 17 (1969) 133-149.

15) J. R. Stephens and W. R. Witzke: J. Less-Common Metals 23 (1971) 325-342.

16) H. P. Gao and R. H. Zee: J. Mater. Sci. Lett. 20 (2001) 885-887.

17) E. M. Savitskii, M. A. Tylkina, S. I. Ipatova and E. I. Pavlova: Met. Sci. Heat Treat. 2 (1960) 483-486.

18) S. Shimakawa, N. Sekimura and N. Nojiri: Proc. The 2002 Symp. on Nuclear Data, (2003) pp. 283-288.

19) C. H. M. Broeders and A. Yu. Konobeyev: J. Nucl. Mater. 328 (2004) $197-214$.

20) J. Moteff, D. J. Michel and V. K. Sikka: Nucl. Metall. 18 (1973) 198211.

21) R. C. Rau and J. Moteff: Radiat. Eff. 8 (1971) 99-105.

22) B. N. Singh, A. J. E. Foreman and H. Trinkaus: J. Nucl. Mater. 249 (1997) 103-115. 